\title{
“Our Organization Deals with People, not with Products”: Perceptions of School Organizational Patterns
}

\author{
By Tamar Chen-Levi* \& Yaffa Buskila ${ }^{+}$
}

This article is part of a wide-scope research examining teachers' perceptions regarding the organizational profile of their school. Research participants were asked about nine parameters that outline the school's organizational structure (Chen-Levi, 2019). Main research questions were: How do the three different groups of position-holders in the school- administrative staff, homeroom teachers, and subject-matter teachers - perceive the organizational profile of their school? What is the importance of each parameter that comprises a school's organizational profile? A loglinear analysis was performed to test whether the three groups differed in the way they related to these parameters. Differences or similarities in the faculty's perception of the school will have implications on the staff's internal cohesion, quality of its communication and staff members' motivation to contribute to change-related tasks that require a long-term view. Analysis of teachers' responses produced a picture according to which the criteria they regard as central to the school's organizational structure are: curriculum content and teaching methods, as well as innovation and changes in the organization. These areas are cornerstones in education. They stressed the need to expose students to a rich and varied education, challenging and encouraging curiosity in many disciplines by means of creative tools and constant innovation.

Keywords: organizational profile, school structure, teachers' perceptions, bureaucratic-hierarchical approach, systemic approach.

\section{Introduction}

Literature on organizational structures presents several theories for understanding them, beginning with the structural theory that regards the organization as a complex and sophisticated social machine, through newer approaches which perceive it as an open system, constantly learning and developing through interaction with its environment, feeding from it and contributing to it (Chen-Levi, 2016; Goldspink \& Kay, 2003; Levin \& Schrum, 2013; Shaked \& Schechter, 2013; Senge, 2006).

Theoretical approaches employed to understand organizations appear to prove that they usually possess several common traits: constant production of desired products in order to procure the essential resources to perpetuate the organization's existence and functioning; systematic work distribution, where every individual in the organization is delegated a set of actions that combine into one well-defined role; activation of coordination processes and control mechanisms in order to achieve maximal efficacy under the existing conditions, and institutionalization of

\footnotetext{
*Lecturer, Department of Education, Bar-Ilan University, Ramat Gan, Israel.

${ }^{+}$Lecturer, Orot Israel College of Education, Rehovot, Israel.
} 
organizational processes; behaviors and interactions between components within the organization as well as between it and its outside environment, and more. The differing extents to which these traits exist in each organization enable us to describe and characterize each organization's unique profile and distinguish it from other social frameworks (Chen-Levi, 2019).

Despite their common characteristics, organizations can differ from each other dramatically in their conduct as well as in the manner in which they attempt to achieve their goals. A school is an organization characterized by pedagogical work and by the unique interrelation between its components (Chen-Levi, 2019). In order to understand its functioning, it is essential to understand its various subcomponents, and the interaction between them. Whether a school's structure is bureaucratic-hierarchical or systemic is of utmost significance, thus this may even be deemed its central characteristic. This article attempts to assess perceptions of schools' organizational structures by school faculty and to understand the organizational processes occurring in them (Chen-Levi, 2016; 2019).

\section{Criteria for Assessing a School's Organizational Profile}

Seven of the nine criteria for assessing a school's organizational model were set by Sharan and Shachar (1990) based on a distinction made by Janowitz (1969) between two organizational models: the specialization model and the aggregation model. The specialization model is characterized by seeing the organization as a construct composed of various parts, each possessing its own distinct specialization and clear professional division. For example, teaching methods, school procedures, and school programs fall into this model. This approach is typical of organizations tending toward the bureaucratic-hierarchical model, whereas the aggregation model is based on a holistic approach toward the organization and the entirety of its components, and is more characteristic of a systems thinking model organization.

Based on Janowitz's model, criteria for assessing school functionality have been created, and then updated for schools' changing reality. These include the various aspects of school organization: complexity of staff organization, delegation of authority, curriculum content flexibility, teacher compartmentalization, flexibility during teaching, relating to change, and agreement regarding the school's policies and ideology. Each of these factors is rated on a ten-degree scale ranging from bureaucratic-hierarchical model characteristics on one end to systemic model characterizations on the other. In order to better differentiate the two models, we will illustrate how each of the above-specified areas is expressed in the bureaucratic-hierarchical model compared to how it is expressed in the systemic one. In a later research, two additional criteria were added: information overload and time pressure (Chen-Levi, 2019). These criteria emanated from a wide variety of research literature (Chajut \& Algom, 2003; Eppler \& Mengis, 2004; Jett \& George, 2003; Kock, 2000; Santavirta, Solovieva \& Theorell, 2007; Sutcliffe \& Weick, 2008). These criteria present a broad picture of a school's organizational patterns and form its organizational profile. 
The extent to which each of the nine criteria is present was graded on a scale from 1-5, from the bureaucratic-hierarchical model (1) to the systemic model (5).

1. Complexity of staff organization: the existence of a network of teams serving as the basis for creating a multidisciplinary curriculum

2. Delegation of authority: this area is an indication of structural and functional decentralization. Authority delegation allows for identifying problems and solving them, as well as for professional enrichment, mutual support and greater involvement on teachers' part.

3. Flexibility regarding curriculum: planning the curriculum, i.e. the choice and organization of meaningful study areas, constitutes the core of pedagogical activity within a school. It includes defining strategies and educational goals, as well as reflecting the school's educational approach.

4. Teacher compartmentalization into their subject-matter area: the idea of cooperation among teachers and between disciplines reveals the type of connections existing within a school. The establishment of teacher teams for interdisciplinary learning defines the school's approach to compartmentalization vs. holism.

5. Flexibility in teaching/learning times: the perception of time and the manner in which it can best be used stem from a school's ideology and organizational patterns.

6. Relating to change as an all-encompassing institutional process: the view of change as applying to the entire institution indicates that the latter is able to cope more efficiently with pedagogical and technological innovations. The participation of all school staff members in the innovation process indicates its systemic organizational structure.

7. Agreement and clarity concerning the school's policy and ideology: defining a uniform approach concerning the school's ideology, policies, and professional outlook among management and teachers is a principle of organization and personal relationships in all ranks of the organizational structure. A school's ideology and policies contribute to coordination and interaction between all of its subsystems (Borgatti \& Foster, 2003; Daft, 1998; Whyte \& Ellis, 2004; Wohlstetter, Malloy, Chau \& Polhemus, 2003).

8. Time pressure: the need to cope with many tasks and goals within limited time may cause a discrepancy between the system's demands and teachers' ability to fulfill them. As a result, the sense of time pressure among faculty members increases, and performance quality may drop at times. Conversely, a low level of time pressure may attest to an organizational structure that enhances participation and encourages communication and distribution of tasks.

9. Coping with information: school faculty are exposed to large amounts of information throughout their work routine, such as curricula, changing regulations, new teaching methods, internal school information, staff meetings and PTA meetings'. Due to this abundance of information, very little sorting of information that enters the school is actually done, which 
may cause a feeling of overload that could damage the management of the system and its subsystems.

Diagnosing a school's organizational structure on a scale ranging from bureaucratic-hierarchical to systemic is of great importance, since it allows for describing and understanding the sum total of interpersonal, professional, and group processes occurring in the school, as well as the mode of staff organization and work methods.

However, even after these nine criteria are examined, the question arises whether the staff sees itself as being responsible for each of these criteria in equal measure. For instance, do they perceive the extent of flexibility in teaching times as being as much their responsibility as is the extent of authority delegation? If certain areas are perceived as being outside the realm of teachers' responsibility, or as being dictated from above (for instance by the Education Ministry), this may affect their assessment of the school's organizational profile.

It is important to remember that there are additional factors affecting the perception of a school's organizational profile. The purpose of this paper is to explain the possible effects of parameters such as role (principal/vice principal/ coordinator/teacher etc.) and educational framework (elementary, middle and high school) on staff members' perception of the organization.

Therefore, this research attempts to answer the question: how do the different categories of school faculty perceive these nine parameters? As mentioned above, the method chosen to seek the answer to this question is a qualitative one. Another question explored here is whether the groups differ in their manner of relating to these criteria, which is examined via a loglinear analysis. This analysis presents a complete picture drawn from the experiences and perception of school faculty members.

The present research hypothesis states that the differences or similarities between the various school staff members' perceptions will have implications on the staff's internal cohesion, on the quality of communication between its members, on their motivation to contribute to change-related tasks requiring longterm vision, and on their readiness to commit and take responsibility.

\section{Method}

The research method chosen for this study is qualitative and criterion-focused. It was constructed out of combination of six methodologies, which reflect slightly different approaches (Shakedi, 2011). This methodology is somewhat more identified with the post-positivist approach than with other research strategies. Our preference for a criterion-focused method resulted from the scope of this research, the specific teacher populations examined in it, and its being part of a larger, mixed-method research. 
This methodology ${ }^{1}$ is different from the interpretive or narrative type. It stresses analytical research abilities over intuitive ones, meaning that the research is conducted with close attention to external criteria (theories, principles, categories) from beginning to end (Shakedi, 2011).

Though the criteria-guided principles underlying the methodology are closer to the positivist approaches of the traditional quantitative research, it (including all of its components) belongs to the area of qualitative research. In fact, the mere choice of words and language as a means of conducting and setting research criteria is a deviation from the absolute positivist research approach. Therefore, despite being presented alongside a quantitative research, it presents a verbaldescriptive picture speaking for itself. Some call this the "positivist-qualitative" research (Guba \& Lincoln, 2005: 191-215). This paper's criteria-driven methodology is based on the literature review presented at the beginning of this paper, forming the theoretical background for this research. The questions the teachers were asked are descriptive and directly related to theoretical criteria, allowing for a clear and focused picture.

\section{Participants}

The research population included administrative teams ${ }^{2}$, homeroom teachers, and subject-matter teachers in elementary and high schools in the Jewish public and public-religious school systems.

Participants consisted of 539 teachers - 486 female and 53 males, teaching in elementary and high schools. 189 were members of administrative staff, 165 were homeroom teachers, and 185 were subject-matter teachers; $66 \%$ of teachers had a BA and 34\% had an MA or a higher degree. The number of teachers with 1-10 years' seniority in teaching was similar to the number with 11-20 years' seniority; a slightly lower number had 21-31 years' seniority, and a small percentage (7.1\%) had teaching seniority of over 31 years.

The research included 38 schools - 21 elementary schools $(55.3 \%)$ and 17 high schools (44.7\%). The schools were chosen randomly and had the following geographical distribution: 23 schools $(60.52 \%)$ in the central district, 9 schools (23.68\%) in the Tel Aviv district, 3 schools (7.89\%) in the southern district, 2 schools $(5.26 \%)$ in the Jerusalem district, and one school $(2.63 \%)$ in the northern district.

\footnotetext{
${ }^{1}$ As aforementioned, the current study is a part of a larger research project examining differences among principals' and teachers' perceptions of information overload and time pressure in schools with different organizational structures (Chen-Levi, 2019).

${ }^{2}$ Administrative team' implies principals, assistant principals, counselors and pedagogical advisors.
} 


\section{Study Process}

A sample of 99 teachers from the main research pool answered the open questions. These teachers were asked to explain in writing what each of the nine parameters meant to them. They were also requested to provide an example from their personal experience in school. The nine parameters the teachers were asked to refer to were: 1 . Complexity of staff organization 2. Delegation of authority in the school 3. Extent of flexibility regarding curricular material 4. Extent of subjectmatter teacher compartmentalization 5. Flexibility in teaching/learning times 6 . Extent of relating to change as an all-institutional process 7. Extent of agreement and clarity concerning the school's policy and ideology 8 . Time pressure and 9 . Dealing with information in the school. The total of teachers' statements was derived from their responses about different realms of their work and the way their school is run. A corpus of responses was created for the purpose of content analysis.

\section{Results}

Teachers' responses were classified into a detailed schema which included a distinction between two general categories of statements concerning school organizational structures: the nature of teamwork, authority delegation ladder, types of teaching methods and curriculum, innovation and change, and feelings of overload in coping with information. The second part of the qualitative analysis constructed a corpus of teacher statements that served to form a loglinear analysis which facilitated the analysis of variable interactions with an ANOVA.

The general categories were designed according to their contents: the nature of teamwork (team composition, roles and responsibilities, perception of teamwork within the school), authority delegation ladder (administrative team's areas of authority, centralization of authority by the principal, teacher subordination- role flexibility, loneliness on the job, authority delegation), type of teaching methods and curricula (permanent curriculum, set schedule, flexible or changing schedule, flexibility and accommodation in teaching and learning, subject integration, subject separation, teacher cooperation), innovation and change (cooperation in setting goals and policies, teachers' resistance to change, feeling of alienation and distance among teachers, striving for cooperative work, lack of implementation of ideas and decisions, lack of cooperative brainstorming and action, ambiguous school goals and policies), and feelings of overload and coping with excessive information (suitability of information to role-holders, information filtering and classification by the administrative team, reactions to new information).

The classification system was such that each category was given a number (nature of teamwork $=1,000$; delegation of authority $=2,000$; type of teaching methods and curriculum $=3,000$; innovation and change $=4,000$ overload $=$ 5,000 ; coping with information $=6,000$ ), and the subcategories were decimally numbered. For example, team composition $=1,100$, team responsibilities $=1,200$ 
and so on. The classification of statements by category was done according to the nature of the statement. Classification into categories was done twice, at different times, in order to reach high agreement ratios.

A total of 1630 statements were classified. Image 1 shows the percentage distribution of all teachers' statements (1630) concerning school organization according to the above six categories.

Image 1. Distribution of Statements concerning school Organizational Structure by the Six Categories

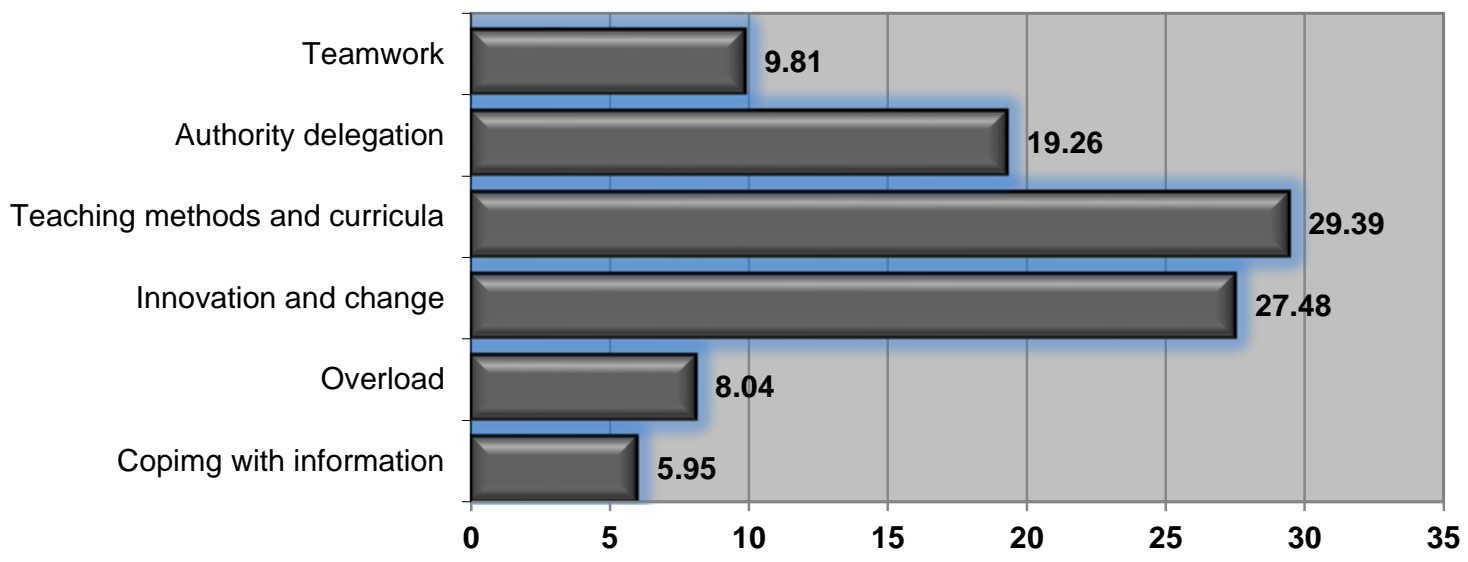

\section{Loglinear Analysis Results}

The responses concerning schools' organizational patterns were sorted into three groups according to the responder's position: administrative staff member, homeroom teacher, or subject-matter teacher. Table 1 presents the frequency distribution of the three groups in the total parameter of perception of school organizational model, as well as the six statement categories.

The data was analyzed using a loglinear model in accordance with Schoonen and de Glopper's (1996) research, which is a method of analyzing categorical variables similar to the ANOVA. Like the ANOVA, this analysis allows for determining the interaction between two or more variables and the size of several distinct parameters. In the statement analysis there were 18 cells created from the tested variables: position (3) x categories (6). The position variable served as the independent variable and the categories served as dependent or explained variables.

Since the division into groups by role is not equal in size, the main effect may be an artificial. To avoid this, the frequencies were adjusted to suit a standard group size. The smaller group size was $\left(n_{1}=n_{2}=n_{3}=29\right)$. The frequency of statements of the larger groups was therefore proportionally decreased ${ }^{3}$. If an effect is found among the groups, it will therefore be interpreted as a real result of a difference in statements by job different role-holders.

\footnotetext{
${ }^{3}$ Proportion calculation $29 / 35=0.83$.
} 
Vol. 9, No. $1 \quad$ Chen-Levi \& Buskila: "Our Organization Deals with People, not with...

Table1. Frequency Distribution of the Six Categories according to the Three Roles of School Staff

\begin{tabular}{|c|c|c|c|c|c|}
\hline $\begin{array}{l}\text { The categories } \\
\text { derived from } \\
\text { statement } \\
\text { analysis }\end{array}$ & & $\begin{array}{c}\text { Administrative } \\
\text { staff } \\
(n=35)\end{array}$ & $\begin{array}{c}\text { Homeroom } \\
\text { teachers } \\
(\mathrm{n}=35)\end{array}$ & $\begin{array}{c}\text { Subject-matter } \\
\text { teachers } \\
(n=29\end{array}$ & $\begin{array}{l}\text { Total } \\
(\mathrm{n}=99)\end{array}$ \\
\hline \multirow[t]{2}{*}{$\begin{array}{l}\text { Nature of } \\
\text { teamwork }\end{array}$} & $\mathrm{N}$ & $\begin{array}{l}74 \\
(61)\end{array}$ & $\begin{array}{c}51 \\
(42)\end{array}$ & 35 & $\begin{array}{c}160 \\
(138)\end{array}$ \\
\hline & $\%$ & 11.1 & 8.8 & 9.2 & 9.81 \\
\hline \multirow[t]{2}{*}{$\begin{array}{l}\text { Authority } \\
\text { delegation ladder }\end{array}$} & $\mathrm{N}$ & $\begin{array}{l}111 \\
(92)\end{array}$ & $\begin{array}{l}112 \\
(93)\end{array}$ & 91 & $\begin{array}{c}314 \\
(276)\end{array}$ \\
\hline & $\%$ & 16.6 & 19.3 & 23.9 & 19.26 \\
\hline \multirow[t]{2}{*}{$\begin{array}{l}\text { Nature of } \\
\text { curriculum and } \\
\text { teaching method }\end{array}$} & $\mathrm{N}$ & $\begin{array}{c}194 \\
(161)\end{array}$ & $\begin{array}{c}175 \\
(145)\end{array}$ & 110 & $\begin{array}{c}479 \\
(416)\end{array}$ \\
\hline & $\%$ & 29.0 & 30.1 & 28.9 & 29.39 \\
\hline \multirow[t]{2}{*}{$\begin{array}{l}\text { Organizational } \\
\text { innovation and } \\
\text { change }\end{array}$} & $\mathrm{N}$ & $\begin{array}{l}193 \\
(160)\end{array}$ & $\begin{array}{c}171 \\
(142)\end{array}$ & 84 & $\begin{array}{c}448 \\
(386)\end{array}$ \\
\hline & $\%$ & 28.9 & 29.4 & 22.0 & 27.48 \\
\hline \multirow[t]{2}{*}{$\begin{array}{l}\text { Sensation of } \\
\text { overload }\end{array}$} & $\mathrm{N}$ & $\begin{array}{c}51 \\
(42)\end{array}$ & $\begin{array}{l}45 \\
(37)\end{array}$ & 35 & $\begin{array}{c}131 \\
(141)\end{array}$ \\
\hline & $\%$ & 7.6 & 7.7 & 9.2 & 8.04 \\
\hline \multirow[t]{2}{*}{$\begin{array}{l}\text { Coping with } \\
\text { information }\end{array}$} & $\mathrm{N}$ & $\begin{array}{l}45 \\
(37)\end{array}$ & $\begin{array}{l}26 \\
(22)\end{array}$ & 26 & $\begin{array}{c}97 \\
(85)\end{array}$ \\
\hline & $\%$ & 6.7 & 4.6 & 6.8 & 5.95 \\
\hline \multirow[t]{2}{*}{ Absolute total } & $\mathrm{N}$ & $\begin{array}{c}668 \\
(533)\end{array}$ & $\begin{array}{c}580 \\
(481)\end{array}$ & 381 & $\begin{array}{c}1629 \\
(1415)\end{array}$ \\
\hline & $\%$ & 100 & 100 & 100 & 100 \\
\hline
\end{tabular}

Note: the numbers in parentheses express the frequency of perceptions after adjusting for a standard group size. Calculated relativity $29 / 35=.83$

The analysis was carried out via a saturated model that contained four parameters: the constant term; two variables for "role" and "different categories", and a parameter for the interaction between these variables. The model allows for a reliable description of the variables being studied. All observed statement frequencies can be described with a constant $(\mathrm{C})$ : a main effect to the role variable $(\mathrm{R})$; type of category $(\mathrm{P})$; and an interaction effect between the variables (RxP). This interaction is especially interesting since it corresponds to the question "is there a difference in the frequency of statements in the different categories between school faculty members fulfilling different roles". The existence of an interaction between the "role" variable and the categories indicates that different role-holders produced different amounts of statements in categories concerning the school's organizational model.

Parameters $\mathrm{R}$ and $\mathrm{P}$ fit the following questions, respectively:

1. Do teachers in different roles differ in the frequency of statements they make concerning the school's organizational model?

2. Do the various categories differ in frequency? 
The effect size can be expressed in standardized values (Z). An effect with absolute corrected values higher than 1.96 is considered significantly different $(\mathrm{p}<0.05)$. Frequencies higher than expected are predicted by positive values; frequencies lower than predicted are expressed by negative values; a lack of effect is expressed by the value 0 or by values close to 0 . Table 2 presents the standardized values $(Z)$ for the main effects, and the interaction effect of the two values.

Table 2. Standardized Values (Z) for the Main Effects and for the Interaction Effect Roles x Perception Category

\begin{tabular}{|c|c|c|c|c|}
\hline Effect type & Parameter & Estimate & Std. Err. & $\mathrm{Z}$ \\
\hline \multirow[t]{14}{*}{$\begin{array}{l}\text { Role } \mathrm{x} \\
\text { Category }\end{array}$} & $\begin{array}{c}\text { Administrative staff } \mathrm{x} \\
\text { teamwork }\end{array}$ & .12 & .10 & 1.29 \\
\hline & $\begin{array}{c}\text { Administrative staff } \mathrm{x} \\
\text { authority }\end{array}$ & -.19 & .08 & $-2.28 *$ \\
\hline & $\begin{array}{l}\text { Administrative staff } \mathrm{x} \\
\text { curriculum contents and } \\
\text { teaching methods }\end{array}$ & -.02 & .07 & -.035 \\
\hline & $\begin{array}{l}\text { Administrative staff } \mathrm{x} \\
\text { change and innovation }\end{array}$ & .07 & .07 & .95 \\
\hline & $\begin{array}{c}\text { Administrative staff } \mathrm{x} \\
\text { overload }\end{array}$ & -.08 & .11 & -.73 \\
\hline & $\begin{array}{l}\text { Administrative staff } \mathrm{x} \\
\text { coping with information }\end{array}$ & .1 & .09 & 1.11 \\
\hline & $\begin{array}{l}\text { Homeroom teachers } \mathrm{x} \\
\text { teamwork }\end{array}$ & -.04 & .11 & -.40 \\
\hline & $\begin{array}{l}\text { Homeroom teachers } \mathrm{x} \\
\text { authority }\end{array}$ & .03 & .08 & .36 \\
\hline & $\begin{array}{l}\text { Homeroom teachers } \mathrm{x} \\
\text { curriculum content and } \\
\text { teaching methods }\end{array}$ & .08 & .07 & 1.04 \\
\hline & $\begin{array}{l}\text { Homeroom teachers } \mathrm{x} \\
\text { change and innovation }\end{array}$ & .15 & .07 & $2.16^{*}$ \\
\hline & $\begin{array}{c}\text { Homeroom teachers } \mathrm{x} \\
\text { overload }\end{array}$ & -.00 & .12 & -.04 \\
\hline & $\begin{array}{l}\text { Homeroom teacher } \mathrm{x} \\
\text { coping with information }\end{array}$ & -.22 & .09 & $2.44 *$ \\
\hline & $\begin{array}{c}\text { Subject-matter teachers } \mathrm{x} \\
\text { teamwork }\end{array}$ & -.08 & .10 & -.08 \\
\hline & $\begin{array}{c}\text { Subject-matter teachers } \mathrm{x} \\
\text { authority }\end{array}$ & .16 & .08 & $2.0^{*}$ \\
\hline
\end{tabular}


Vol. 9, No. $1 \quad$ Chen-Levi \& Buskila: "Our Organization Deals with People, not with...

\begin{tabular}{|c|c|c|c|c|}
\hline & $\begin{array}{l}\text { Subject-matter teachers } \mathrm{x} \\
\text { curriculum content and } \\
\text { teaching methods }\end{array}$ & -.06 & .07 & -.86 \\
\hline \multirow{6}{*}{ Role } & $\begin{array}{l}\text { Subject-matter teachers } \mathrm{x} \\
\text { change and innovation }\end{array}$ & -.22 & .07 & $3.24 * *$ \\
\hline & $\begin{array}{c}\text { Subject-matter teachers x } \\
\text { overload }\end{array}$ & .08 & .11 & .73 \\
\hline & $\begin{array}{l}\text { Subject-matter teachers } \mathrm{x} \\
\text { coping with information }\end{array}$ & .12 & .09 & 1.33 \\
\hline & $\begin{array}{c}\text { Administrative team } \\
\text { members }\end{array}$ & .19 & .04 & $4.30^{* * *}$ \\
\hline & Homeroom teachers & -.02 & .05 & -.40 \\
\hline & Subject-matter teachers & -.17 & .04 & $4.25^{* * * *}$ \\
\hline \multirow{6}{*}{$\begin{array}{l}\text { Category } \\
\text { types }\end{array}$} & Teamwork & -.37 & .08 & $4.70^{* * *}$ \\
\hline & Delegation of authority & .35 & .06 & $5.98 * * *$ \\
\hline & $\begin{array}{l}\text { Curriculum content and } \\
\text { teaching methods }\end{array}$ & .75 & .05 & $14.46^{* * *}$ \\
\hline & $\begin{array}{c}\text { Organizational innovation } \\
\text { and change }\end{array}$ & .65 & .05 & $12.06 * * *$ \\
\hline & Feeling of overload & -.53 & .08 & $-6.43 * * *$ \\
\hline & Coping with information & -.85 & .05 & $17.0^{*} * *$ \\
\hline
\end{tabular}

$* \mathrm{p}<.05, * * * \mathrm{p}<.001$

Note: the minus [-] sign expresses frequencies that were lower than predicted in the mean

The data in table 2 shows that in the standardized values $(Z)$ the size of the role effect $(\mathrm{R})$ is 4.30 for administrative staff, -0.40 for homeroom teachers and 4.25 for subject-matter teachers. The main significant effect of $\mathrm{R}$ for the administrative staff and subject-matter teachers indicates that there is a statistically significant difference in the frequency of statements uttered by the different roleholders. This means that the frequency of statements about the organizational nature of the school among administrative staff is higher than the mean. In contrast, among subject-matter teachers the frequency is significantly lower than the mean. The frequency of statements of administrative staff was 553 in adjusted values, whereas the frequency of statements among subject-matter teachers was 381.

However, no significant difference was found between the frequency of statements about the organizational nature of the school made by homeroom teachers (481 in adjusted standardized values) and the frequency of those made by administrative staff and subject-matter teachers.

The main effect on category type $(\mathrm{P})$ indicates that statements from different categories appear in different frequencies. In the three categories: authority delegation ladder, curriculum content and teaching methods, and organizational change and innovation, the effect of $\mathrm{P}$ was significantly positive (range: 5.9812.06). In the three categories: teamwork, feeling of overload, and coping with information, however, $\mathrm{P}$ was found to be negative (range: $-4.70-(-17.0)$ ). That is, in the three categories: authority delegation ladder, curriculum content and 
teaching methods, and organizational change and innovation, the frequency of statements was above the mean, and in the three categories: teamwork, feeling of overload, and coping with information, it was lower than the mean (image 1).

It may be interesting to note the differences between the three role groups and their statements. This can be demonstrated in the size of the effects shown in table 3. It shows a clear interaction between administrative staff $x$ authority delegation ladder $(Z=2.28)$, homeroom teachers $x$ organizational change and innovation $(Z=2.06)$, homeroom teachers $x$ coping with information $(Z=2.44)$, subject matter teachers $\mathrm{x}$ authority delegation ladder $(\mathrm{Z}=2.0)$, and subject-matter teachers $\mathrm{x}$ organizational change and innovation $(Z=3.14)$.

The findings mean that among administrative staff there is a low frequency of statements concerning authority and its delegation, whereas among subject-matter teachers there is a high frequency of statements on that topic ${ }^{4}$, which means that administrative teams focus less on the authority delegated to them on their job, whereas subject-matter teachers are more occupied with it.

Additionally, findings show that among homeroom teachers and subjectmatter teachers there is a high frequency of statements concerning innovation and change, as well as coping with information. This indicates that subject-matter and homeroom teachers attribute importance to innovation and change that impact them directly, and homeroom teachers also attribute importance to coping with information.

To summarize, the findings of the loglinear analysis point to the possibility of distinguishing between the three groups of school role-holders according to the three categories: authority delegation, organizational change and innovation, and coping with information.

\section{Discussion}

The second part of this article is based on teachers' responses to questions concerning various aspects of school organization. The content analysis illuminated some of the hidden connections that have not been exposed in previous research. The qualitative part is intended to examine the informal and unwritten norms created by the interactions of the different groups that constitute the school organization (Oplatka, 2017).

\section{Organization of Teamwork}

Teachers' responses indicate that there were differences in their perceptions of teamwork at the school. Administrative staff had the largest number of statements concerning teamwork within the school, but their treatment of the subject was mostly on a very superficial level, sometimes sounding more like slogans. Their statements tended to be theoretical rather than providing actual descriptions of

\footnotetext{
${ }^{4}$ The number of cases in a cell is compared to the expected number of cases in a cell based only on the frequency of the line and the column independently.
} 
teamwork in the school, for example; "our organization is one that deals with people, not with products", or "our school always strives to achieve excellence". Their descriptions of the school's organization lacked personal expression, and their statements described an overview of school reality rather than an insider's view, for example: "the school's aspiration is teamwork, work in sub-groups, and cooperation among all faculty and staff members".

A possible explanation for administrators' view of teamwork can be found in Glicksman's (2008) research, stating that the school's administration is the spotlight and compass that is supposed to illuminate the entire school's path. Thus, the administrative staff must possess a vision that can guide all school processes. Shachar (2007) adds that the school's administrative staff members usually determine its social and educational policies, and as a result see themselves responsible for setting goals and leading change and innovation. All these have a direct effect on their very broad, general views. Perhaps these statements also stem from the administration's constant need to market the school, and marketing is often based on clichés and slogans.

In contrast, the homeroom teachers spoke of teamwork from a more personal, subjective viewpoint. The homeroom teacher is expected to possess a broad organizational view; he/she shapes students' personalities, tends to their varied needs and is supposed to help their values grow along with their knowledge, while also keeping in touch with parents. Homeroom teachers' statements about teamwork indicated that it is an integral part of their work routine. They evaluated teamwork from their personal experience and from an insider's point of view. Their answers refer, for instance, to methods of performing teamwork: "First the teachers work in small teams and then in larger committees until they reach a final decision". Or, for another example, they provide assessments of the teamwork in their school: "there is a lot of cooperation between teams, and decisions are often reached by teams on a class-wide level".

Homeroom teachers also note the connection between teamwork and high motivation: "motivation in our school is high, we select the relevant educational information in teams", and the implications of teamwork on other aspects of work in school, such as responsibility and authority delegation, are described: "I think it's important to hear teachers' opinions and share responsibility", as well as "every staff member has the right to make decisions about his/her main occupation in school".

Finally, homeroom teachers also pointed to the benefits of teamwork. "When we work in teams, we have a free hand and the principal is willing to listen to us". They spoke of the conditions facilitating productive teamwork, such as cohesiveness, group size, and well-defined responsibilities. Thus it is possible to find statements concerning teachers' cohesiveness such as "I expect teachers to work in more cohesive teams"; statements about team size such as "the teams in the school are very large and it's not easy to work this way"; and statements about the importance of firmly establishing teamwork as a feature of the school system: "the team meets once a week to discuss details, receive updates and learn".

To summarize, homeroom teachers' discussion of teamwork was personal, and stemmed from their work in the field. They expressed difficulties, described 
instances of success, and pondered ideas on ways to make teamwork more fruitful and contribute to teachers' feelings of empowerment and belonging: "the teams in school work efficiently and advance toward desired results", and "the school tends to rely on the teams to make wise, correct decisions that are beneficial both to the school and to the students, and advance its goals".

The subject-matter teachers had the lowest number of statements concerning teamwork. This can be explained by their specific placement in the hierarchy of the school and the perception of their role in the organization: subject-matter teachers teach a specific subject in different classes, are not expected to make decisions concerning school policy, and are not committed to homeroom hours and to social activities in the classes they teach. It is plausible that the character of subject-matter teachers' role minimizes expectations as far as their participation in shaping the school's organizational or social policy.

However, the subject-matter teachers' answers indicated the need for more participation on their part as well as a clearer policy in this regard: "there's a middling organization of teams to make decisions in the school; in some areas it exists and in some it doesn't", and also: "in terms of the narrow division, the English staff works well, but on the broad organizational level the school is lacking”.

Subject-matter teachers seemed to regard teamwork as an important tool for solving problems encountered in their work: "once a week there is a class-wide meeting to solve problems", and "teamwork is for resolving problems and addressing issues".

\section{Hierarchy and Authority Delegation in School}

The administrative staff spoke of a clear need for more control and order in the school system. They viewed the school as a hierarchical organization, with clearly-defined realms of authority and subordination: "teachers don't have full autonomy, there's a hierarchy of principal, then administrative staff, then teachers". Thus, the feeling conveyed to teachers is that "every teacher knows what is expected of him/her", as well as "every meeting is summarized and the protocol is given to the principal", and "the principal has to be notified of every move that is being led by a staff member". Their reference to this issue was direct, for instance: "in our school the administrative staff delegates authority in certain cases", or "there is almost no delegation of authority in our school".

It seems that the rigidity displayed by administrative staff members concerning the issue of authority and its delegation stems from their need for order and control within the organization, as well as from their reporting duty: "previously changes in school were made by the staff, however, this year any changes are made by the principal and vice principal only"; "most decisions and authority are in the principal's hands".

However, when it comes to a teacher's authority within his/her own class, the picture is completely different; "A teacher is the authority within his/her class, both as homeroom teacher or subject-matter teacher". As stated above, there is a 
marked difference between the responsibilities and authority of administrative team members, who have to lead the school in a general way, managing the staff and making policy decisions, and the authority of teachers who are subordinate to the administration on the one hand, and enjoy authority in their own classrooms on the other.

Another finding was that many of the homeroom teachers and subject-matter teachers referred to feelings of loneliness and confusion within the organization. Statements such as "I often feel like one teacher facing one class and one counselor" and not like a teacher within a whole school organization or "every subject-matter teacher or homeroom teacher deals alone with problems that occur in class". There are also expressions of alienation: "I don't take part in making decisions but have to act according to them", and even lack of motivation: "I feel like I can't be independent in my decisions and have to report every decision I make, which is demotivating, tiring".

As seen in the context of the administrative staff, responses show that there is a clear difference between a teacher's place in his/her class and his/her place in the school as a whole. "I have no independence in certain areas; I do have total independence in my area of teaching - i.e. as far as what to teach when, and the like", or "regarding any decisions concerning the class, the teacher is a small principal". However, the system provides a different perspective: "in school-wide decisions the administration sets the tone", or "on the educational level, the authority is more in the hands of the school" and "in general things like procedures or tasks they don't listen to what I have to say, they just give me instructions".

From the administrative staffs' and homeroom teachers' responses an additional concept surfaces, though it was not explored in this research; that is the concept of 'the teacher from the organizational perspective', dealing with the contradiction between a teacher's place in his/her class and his/her place in the school organization. Most importantly, this is expressed by the teacher's familiarity with the processes to which he/she is obligated as an only teacher in a classroom, vis-à-vis the processes to which he/she is obligated as a member of an organization and a team. This area is worthy of further study aiming to explore the teacher's multi-level commitment in the organizational context.

Among subject-matter teachers the feelings of subordination and loneliness are greater than by homeroom teachers. Their responses show that the built-in contradiction in their role within the organization might even exacerbate these feelings. "There is no delegation of authority, the principal is the one who decides", or "there is no freedom of action for teachers" are some of the responses given. "The discrepancy between their role as teacher and their organizational status is greater. "I am a subject-matter teacher; I work independently without anyone interfering in my professional judgment". Therefore, their feeling of loneliness is also greater than that of homeroom teachers; "every teacher works alone in class, that's how it goes".

Both homeroom and subject-matter teachers referred to the connection between authority delegation and responsibility. They testify that an organization where authority is delegated inspires a greater sense of responsibility and 
cooperation; "there is an atmosphere that encourages taking responsibility in the school" and "the school respects teachers' ability to make decisions".

\section{Curriculum, Teaching Methods and Schedule}

The administrative staff referred extensively to the importance of a set schedule: "in our school the schedule, teaching hours and classrooms are set in advance for the entire school year". There was an assertion that "if you need to switch the place or time of a lesson, that will require complex coordination".

Many statements referred to the need for order and organization in the school as a condition for its improvement. "The schedule is uniform and organized" and "the schedule is preset", and for this reason "every teacher knows when and where he/she has to teach so that no time is wasted".

Additionally, the administrative staff referred to events and processes taking place outside the school which affect what happens inside it: "the schedule and teaching hours are determined by guidelines from the Education Ministry, any change or flexibility in this regard involve changing a lot of other people's plans, so it's complicated"; "almost all of the curriculum contents are dictated by the Education Ministry".

Another important matter arising from participants' statements is treating the classes within a school as separate units rather than as a part of a larger organization: "teaching methods and learning pace change from one class to another". Likewise, the reference to subjects and teaching illustrated decentralization: "there is a clear division of teaching subjects in the school", and "here it's every teacher with his/her own specialty".

A similar approach prevailed among homeroom teachers. They claimed that "there is no flexibility in the system" and "all the content is preset in a predetermined framework by the Education Ministry and by teachers of previous years" and "it's very clear what every teacher's specialization in, and that's what he/she teaches".

However, homeroom teachers referred more than the other two groups to the topic flexibility in teaching, due to their type of work in the classroom. For example, "I try to maintain constancy in the teaching units, but since the school is dynamic, I adjust myself to the changing needs", or "I adjust the content of what I'm teaching to the level of the class and even to the specific student, and don't just work according to the plan and deadlines of the Education Ministry for starting or finishing a topic", and "the range of the subject studied is dictated by the actual conditions on the ground"

Homeroom teachers have more control over the teaching methods administered in their class. They said that "in school the curriculum contents are studied according to each student's ability and progress" and "flexibility is a necessity and improves students' learning in accordance with their needs".

Also, homeroom teachers referred to interdisciplinary learning in school as a necessity stemming from the structure of the curriculum. "The various subjects sometimes converge so that the distinction between them is not clear-cut", or "the 
separation between subjects is pretty clear but there are still some overlaps, so there is actually no total separation"

Both homeroom and subject-matter teachers described the school system as stiff and rigid. "There is almost no flexibility as far as schedule", and "there's a lot of rigidity in the system, it's static".

While among homeroom teachers there were some references to flexibility and to adapting the curriculum to students' needs, among subject-matter teachers most statements indicated a rigid distinction between the subjects. "There is no subjects", and as a result "it's each to his/her own subject" and "we are all subordinate work in teams, contents do not overlap", or "there is no connection between to the preset program".

\section{Organizational Change and Innovation}

The administrative staff referred on the one hand to general statements such as "change is a way of life in school" and "we have the ability to change and impact" as well as "our school always welcomes teachers' innovation"; on the other hand, they also referred to the many difficulties involved in implementing changes in the school, such as motivating all teachers to participate: "It's impossible to implement change without partners", and "implementing change in a school is a process, and there has to be some openness to it on the part of the teachers".

They also spoke of the difficulty in maintaining change over time, and in implementing changes and new decisions in school. "Even though the teams are aware that their work has to be examined based on the school's goals, they don't always work accordingly" and "even if a change is implemented in the school, it doesn't affect everyone".

Another difficulty that administrative staff members tend to express pertains to including everyone in the school in order to create a sense of belonging, especially among subject-matter teachers. "There is a desire to and get subjectmatter teachers to participate, but there are curriculum limitations", and "ideally we'd like to involve the subject-matter teachers in study tasks and interdisciplinary programs, but in reality, they aren't at school every day so it's difficult to coordinate". Another statement was "the subject-matter teachers are barely interested in what's being taught in other classes".

Another aspect that is referred to is finding the correct balance between the amount of changes that a school incorporates and the amount of change that its teachers can actually assimilate. "Innovation is very important but there has to be a limit", they say, as well as "the principal wants to apply changes and innovations. Some of them are implemented and some are not" because "change and innovation do happen in our school but are not assimilated by the entire staff".

Finally, the administrative staff also said that "you have to dedicate time to the school and its goals", and "hopefully the change will be assimilated by all the teachers", since "change refreshes the staff and adds new strength". 
Somewhat like the administrative staff, homeroom teachers too raised problems regarding the implementation of changes within the school. They noted that "there is no set time in the schedule when we sit down to re-examine our goals". They also said that "there is no constant teamwork, thus we lack the benefit of exchanging ideas".

Another point raised by the homeroom teachers was their objection to change and innovation. "We object to changes in the school despite the fact that they advance the faculty and students" and "changes in the school cause a lack of clarity and confusion about what is going on in the school".

Some utterances pertained to homeroom teachers' sensations of alienation from the school system. "I don't feel like a partner of other teachers", or "there is no motivation to meet with other teachers very often". There was also a feeling of lack of participation in policy-making: "many times there is a feeling that the principal made a decision based on external causes and that despite the feeling they try to give us in the school, the teachers were not really involved in reaching that decision", or "during teacher meetings teachers do not get a chance to express their opinions". They also noted the need for positive role modeling: "the principal does not really stress implementing decisions, so neither do the teachers, and that way the whole proposed change just totally disappears".

To summarize, it seems that homeroom teachers raise difficulties mainly in two areas: one involves the cohesiveness of school faculty, and the other - a feeling of participation and partnership. "There is a lack of cooperation in school when it comes to making changes", they state, adding that "there's teamwork for decision-making, but in the end you feel like you're one teacher in front of your one class" as well as "sometimes I'm not informed of a change and don't participate in it because I just didn't know about it"; or "there are difficulties in creating productive contacts with other teachers". Finally, it seems that homeroom teachers attribute success in implementing changes within the school to the quality of relationships between faculty members as well as to the extent of cooperation and cohesiveness among them.

A similar mood can be sensed also among subject-matter teachers, together with statements that praise change in schools. "The school doesn't vegetate; every so often there is a meeting to plan out school goals," and "the school is always looking to innovate in various areas, and upgrade itself". Many statements were made about difficulties experienced in these processes: "the faculty needs time to cope with changes" and "we got used to working in a certain way and when a new way is introduced it brings about confusion".

Additionally, many statements mentioned the contribution of staff dynamics to the success of implementing changes in school. "It's necessary to improve the team dynamics" or "we don't always sit together to solve problems, we do that only rarely" and "there is a school policy, but agreement is not always reached among the teachers as to implementing it, and there's not always clarity on this subject".

To summarize, the three groups stated that without understanding, and common learning of the processes in school it will be difficult, or even almost impossible, to accept and preserve change and innovation over time. That is 
because, as they said "if there is no cooperation and harmony among the staff", "...no clear agreement about school policy" and "there is nothing in school that requires the cooperation of teachers teaching various subject-matter" - then "there is a discussion from time to time, but it is not thorough, and we are left with questions". As a result, "it is difficult to accept changes because of the difficulty in accepting new ways to work and this is despite the fact that the administration constantly strives to innovate and progress".

\section{Feelings of Time Pressure and Workload in School}

The administrative staff referred in their answers to the importance of good teamwork, sharing the burden, and high motivation to decrease stress and workload; "in a good team where the workload is shared, the stress and feeling of being overwhelmed by the overload is eased". However, the content analysis also revealed that administrative staff experience a very significant feeling of pressure and overload in their jobs. "Work at school is often done under time pressure" and "there is a large number of tasks in addition to the routine management that must be done". The administrative staff expressed a great deal of empathy regarding the stress and work overload experienced by teachers. "Teachers do express discontent due to the task load" and "Some of the teachers carry too heavy a burden", they said. Trying to explain the situation they added: "this means there's a problem bridging between the system's demands from teachers and their ability to carry out all these tasks".

Administrative staff referred to ways of reducing the feeling of stress and overload among the school faculty. For example, they suggested "working in small teams to lessen the burden" and indicated that productive activity creates high motivation, pointing out that "there is a high level of motivation among the teachers in the school".

In contrast, it appeared that teachers - both homeroom and subject-matter teachers - have made peace with the necessity to live with stress and its implications as a part of their job. "Teachers have many tasks, so there's a gap between the requirements and the ability to carry them out". The feelings of overload and stress are connected to the feeling of loneliness on the job, of which teachers said "we are required to carry out many tasks alone". As a consequence, they said, "there is a feeling of discontent among the staff due to the task overload and the shortage of time".

\section{Coping with Information}

Coping with information was the issue least referred to by all three groups, despite the fact that the amount of information surrounding us is a powerful and useful phenomenon (Taghreed, 2007). One of the ways to explain this is that both the school and the teachers do not truly know how to cope with information effectively. There is no institutionalized, systemic organization, nor a set of 
procedures that govern the way in which information enters schools. As a result, no implementation or processing of information in the organization occurs, and this does not come up in meetings and discussions, thus it is not often referred to by teachers.

The administrative staff's reference to information was, first and foremost, recognizing its importance to the school: "I always welcome new information and am open to innovation. That's also the source of my high motivation to do my job". However, along with this recognition there came a sense of flooding and concern as to the implications of information overload on the teachers: "sometimes there's a feeling of flooding and overload of new information", or "a mass of information is streaming into teachers' hands, causing stress and fear" and also "most of the incoming information causes a feeling of flooding, confusion and stress".

Additionally, of the total sum of responses, there were many references from the administrative staff to dealing with filtering and sorting information. "There is a sorting of information in school according to one's role" and "the information is streamed according to teachers' fields of interest"; "the difference between teachers' interests and their ability to cope with information is taken into consideration"; "the school filters the information and takes whatever is needed and fitting"; "our school chooses the information and adapts it to the individual's position as well as to the entire organization".

The homeroom and subject-matter teachers referred in their answers mainly to the fact that there is a sense of flooding. "The school is exposed to so much information from all directions"; "the school is exposed to new information about teaching methods, curriculum contents, management methods and so on". Furthermore, "there is no explanation of the new information coming into the school"; "there is no reference to new information"; "there is no common processing of information"; "there is no processing of information on the staff level". Therefore "teachers find it hard to understand the right place for new information in school" and "it's hard for us to cope with information we don't understand".

Another issue that came up among homeroom teachers was that "it is not always possible to contain all the information and always discuss it in workgroups" and for that reason "the information gets put away in a locker and stays there".

All three groups appeared to comment on the necessity of new information for the vitality of the educational organization, but at the same time they explained its improper management as a cause of dismay. "The new information allows innovation but it sometimes causes confusion and stress", therefore "there is sometimes objection to and rejection of new information among teachers". However, all groups agreed that a filtering and sorting process is necessary: "there is sorting of information, but there is so much coming in...".

To summarize, school staff members report the massive information overload they experience as part of their job. Since in most cases no system is in place to cope with the information, the overload becomes private instead of remaining organizational. Taghreed (2007) claims that exposure to a great deal of information contributes to "information exhaustion syndrome", explaining that "if we cannot 
find a way to join together the many information streams, we might drown in them".

Many staff members understand that to be successful in their jobs they require high levels of information, however, many teachers report that they suffer from a lack of free time and a feeling of overload at work. There is a feeling among teachers that the information overload is a double-edged sword: it can destroy as much as it can create and benefit. Therefore, teachers seem to learn how to filter information in an almost instinctive manner, rather than in a systematic way on the institutional level. Thus, information management is negatively affected, and essential and relevant information is sometimes not addressed, let alone internalized. Therefore, even though schools are exposed to a great deal of information, they do not acquire practical tools facilitating control of information in time and its translation into a form that may prove to be useful for the organization (Taghreed, 2007).

In summary, teachers' responses and the number of statements they made were found to be significant. The manner in which teachers chose to address specific areas and elaborate on them compared to other areas which they addressed sparsely, may attest to low importance or lack of interest. As stated, the number of responses may indicate the differential importance attributed by each of the three groups to various issues pertaining to school life.

Analyzing teachers' responses shows that the areas perceived by the three groups as central are: curriculum contents, teaching methods, organizational change and innovation. These are indeed the cornerstones of education. Teaching varied contents via creative means facilitates the acquisition of better tools for social functioning, for creating a better, more moral and more educated society. The fact that all three groups address these areas extensively in their responses proves the importance of the need to expose students entering schools to a varied and rich education capable of arousing curiosity, as well as innovating and improving constantly.

Another area that came up in the qualitative analysis was the teacher's place as a member of an organization and an organizational culture. The various expectations from the teacher as an expert in the subjects he/she instructs, and also as a member of an organization, may lead to a feeling of disconnect and isolation. Further investigation would be needed to explore the teacher's perception of his/her place within the organization, and the implications of this perception on processes the teacher may undergo, as well as his/her behavior patterns within the school.

\section{References}

Borgatti, S. P., \& Foster, P. C. (2003). The network paradigm in organizational research: A review and typology. Journal of Management, 29(6), 991-1013.

Chajut, E., \& Algom, D. (2003). Selective attention improves under stress: Impliations for theories of social cognition. Journal of Personality and Social Psychlogy, 85, 231-248.

Chen-Levi, T. (2016). Bureaucratic or Systems Thinking Organizational Profile: Perceptions of Principals and Teachers. In M. Frank, H. Shaked, \& S. Koral-Kordova 
(Eds.), Systems thinking - Foundation, uses and challenges. (pp. 285-315). New York: Nova science.

Chen-Levi, T. (2019). Information overload, time pressure and organizational patterns as perceived by Israeli school staffs. International Journal of Leadership in Education, $1-24$.

Daft, R.L., Murphy, J. and Willmott, H. (2014), Organization Theory and Design: An International Perspective, 2nd ed., Cengage Learning, Hampshire. [Google Scholar]

Eppler, A., \& Mengis, J. (2004). The concept of information overload: A review of literature from organization science, accounting, marketing, MIS, ans related disciplines. The Information Society, 20,325-344.

Goldspink, C., \& Kay, R. (2003). Organizations as self-organizing and sustaining systems: A complex and autopoietic systems perspective. International journal of general systems, 32, 459-474.

Guba, E.G. \& Lincoln, Y.S. (2005). Paradigmatic controversies, contradictions, and emerging confluences. in N.K Denzin \& Y.S. Lincoln (eds.) The Sage handbook of qualitative research (3rd ed.). Thousand Oaks: Sage, pp 191-215.

Janowitz, M. (1969) Institution building in urban education. New York, NY: Russel sage foundation.

Jett, Q. R., \& George, J. M. (2003). Work interrupted: A closer look at the role of interruptions in organizational life. Academy of Management Review, 28, 494-507.

Kock, N. (2000). Information overload and worker performance: A process- centered view. Knowledge and Process Management, 4, 256-264.

Levin, B., \& Schrum, L. (2013). Using systems thinking to leverage technology for school improvement: Lessons learned from award-winning secondary Schools/Districts. Journal of Research on Technology in Education, 46(1), 29-51.

Oplatka, I. (2017). Principal workload: Components, determinants and coping strategies in an era of standardization and accountability, Journal of Educational Administration, 55(5), 552-568.

Santavirta, N., Solovieva, S., \& Theorell, T. (2007). The association between job strain and emotional exhaustion in a cohort of 1,028 Finnish teachers. British Journal of Educational Psychology, 77, 213-228.

Schoonen, R., \& Glopper, K. (1996). Writing performance and knowledge about writing (pp.87-107). In G. Rijlaarsdam, H. van den Bergh, \& M. Couzijn (Eds.), Theories, models and methodology in writing research. Amsterdam, Netherlands: Amsterdam University Press.

Senge, P. (2006). The fifth discipline: The art and practice of the learning organization (revised ed.). New York: Currency, Doubleday.

Shachar, H. (2007). Organizational consultation in schools: Theory, research and practice. Tel-Aviv: Ramot. (Hebrew)

Shaked, H., \& Schechter, C. (2013). Seeing wholes: The concept of systems thinking and its implementation in school leadership. International Review of Education, 59(6), 771-791.

Shkedi, A. (2011). The meaning behind the words. Methodologies of qualitative research: Theory and practice. Ramot, Tel Aviv University. [Hebrew]

Sharan, S., \& Shachar, H. (1990). Organization and Staff Management in Schools. Jerusalem, Israel: Schocken. (Hebrew).

Sutcliffe, K.M., \& Weick, K.E. (2008). Information Overload Revisited. In G. Hodgkinson, \& W. Starbuck (Eds.), Handbook of Organizational Decision Making. (pp. 56-76). Oxford UK: Oxford University Press. 
Vol. 9, No. $1 \quad$ Chen-Levi \& Buskila: "Our Organization Deals with People, not with...

Taghreed, A. G. (2007). Knowledge management in schools and for schools. School Libraries Worldwide, 13(2), 47-48.

Whyte, A., \& Ellis, N. (2004). The power of a network organization: A model for schooluniversity collaboration. Contemporary Issues in Technology and Teacher Education, 4(2), 137-151.

Wohlstetter, P., Malloy, C. L., Chau, D., \& Polhemus, J. L. (2003). Improving schools through networks: A new approach to urban school reform. Educational Policy, 17(4), 399-430. 